\title{
Twenty Years of Transgenic Plants Resistant to Cucumber mosaic virus
}

\author{
Marco Morroni, ${ }^{1,2}$ Jeremy R. Thompson, ${ }^{1}$ and Mark Tepfer ${ }^{1}$ \\ ${ }^{1}$ Plant Virology Group, ICGEB Biosafety Outstation, Via Piovega 23, 31056 Ca' Tron di Roncade, Italy; ${ }^{2}$ Istituto di Patologia \\ Vegetale, Università degli Studi di Milano, via Celoria 2, 20133 Milano, Italy
}

Submitted 21 December 2007. Accepted 4 February 2008.

Plant genetic engineering has promised researchers improved speed and flexibility with regard to the introduction of new traits into cultivated crops. A variety of approaches have been applied to produce virus-resistant transgenic plants, some of which have proven to be remarkably successful. Studies on transgenic resistance to Cucumber mosaic virus probably have been the most intense of any plant virus. Several effective strategies based on pathogenderived resistance have been identified; namely, resistance mediated by the viral coat protein, the viral replicase, and post-transcriptional gene silencing. Techniques using nonpathogen-derived resistance strategies, some of which could offer broader resistance, generally have proven to be much less effective. Not only do the results obtained so far provide a useful guide to help focus on future strategies, but they also suggest that there are a number of possible mechanisms involved in conferring these resistances. Further detailed studies on the interplay between viral transgenederived molecules and their host are needed in order to elucidate the mechanisms of resistance and pathogenicity.

Cucumber mosaic virus (CMV) is the type member of the genus Cucumovirus, family Bromoviridae (Palukaitis and Garcia-Arenal 2003; Palukaitis et al. 1992). Since its first discovery in Michigan and New York States (Doolittle 1916), CMV has been found in most countries of the world and has been identified as the causal agent of several disease epidemics. Its host range exceeds 800 plant species, making CMV one of the most important viruses for its economic impact. Because of its importance and the absence of resistance genes in the germplasm of most crops, CMV has been one of the primary targets for development of transgene-mediated resistance. In compiling a list as complete as possible of articles published in English on CMV resistance transgenes, we found more than 50 papers, which certainly exceeds by far the number of equivalent papers devoted to resistance to any other plant virus. Our aim in reviewing this information is to make apparent the particular features of CMV resistance, to clarify which resistance strategies against this virus are most promising, and to identify interesting areas for further research. There have been two recent reviews (Prins et al. 2008; Sudarshana et al. 2007) covering all the strategies for creating virus-resistant transgenic plants (VRTP); however, by focusing on CMV, the present review will be able to go into greater depth, and this will make it possible to highlight features specific to this virus.

Corresponding author: Mark Tepfer; E-mail: Mark.Tepfer@icgeb.org
The CMV genome is organized into three single-stranded messenger-sense genomic RNAs (RNAs 1, 2, and 3) and two major subgenomic RNAs (RNAs 4 and 4A, which serve for the expression of the 3'-proximal gene of RNAs 3 and 2, respectively). RNAs 1 and 2 code for components of the replicase complex, and RNA 2 also codes for the $2 \mathrm{~b}$ protein, which is expressed from subgenomic RNA 4A and is involved in the suppression of gene silencing. RNA 3 encodes the 3 a protein, which is essential for virus movement, and the coat protein (CP), which is expressed from subgenomic RNA 4. The CP has an important role not only in the formation of the viral particles but also in virus movement, transmission by aphid vectors, and symptom expression. In addition, some CMV isolates include a satellite RNA, which is a small, linear, noncoding, single-stranded RNA that depends entirely on the helper CMV for replication, encapsidation, and transmission but has almost no sequence similarity with the CMV genome. CMV satellite RNAs can modify CMV pathogenicity drastically, worsening or attenuating its symptoms, depending on the satellite RNA and on the host species (Palukaitis and Garcia-Arenal 2003).

Based on their biological, serological, and molecular properties, CMV isolates can be classed in two subgroups, I and II, the former being further divided into subgroups IA and IB. The nucleotide identity between subgroups I and II ranges from 69 to $77 \%$, depending on the RNA species, and within-subgroup identities are generally greater than $95 \%$ (Palukaitis and GarciaArenal 2003). Because most crops are susceptible to both subgroups, one of the major challenges is to create resistance that is effective against the entire diversity of CMV strains. The importance of CMV has led many groups to work on creating transgenes that confer resistance to this virus. Most of this work has been devoted to using viral sequences in resistance transgenes; thus, this review will focus primarily on virus-derived genes.

\section{Transgenic virus-derived resistance.}

Although many viral genes have been transferred to plant genomes since the first reports of CMV-resistant transgenic plants, during the earliest years viral $\mathrm{CP}$ genes were the most used in plant transformation. The first report of stable transformation of a plant with a viral CP gene was in 1985, with the introduction of a gene encoding the $\mathrm{CP}$ of Tobacco mosaic virus (TMV) into tobacco (Bevan et al. 1985). This was quickly followed by the first demonstration of pathogen-derived resistance, which had been hypothesized by Sanford and Johnston (1985), in the pioneering work from the Beachy lab describing CP-mediated resistance (CPMR) to TMV (Powell-Abel et al. 1986). The following year, CPMR was reported for Alfalfa mosaic virus (Tumer et al. 1987b), and CMV (Cuozzo et al. 
1988; Tumer et al. 1987a). Since these early reports, although many resistance strategies have been explored (Fig. 1), CPMR clearly has been the predominant strategy for creating VRTP (Prins et al. 2008; Sudarshana et al. 2007).
There are principally two experimentally well-established mechanisms at work to explain virus-derived resistance, one in which the effector is a protein and another in which it is the RNA transcribed from the transgene; in the latter case, resis-

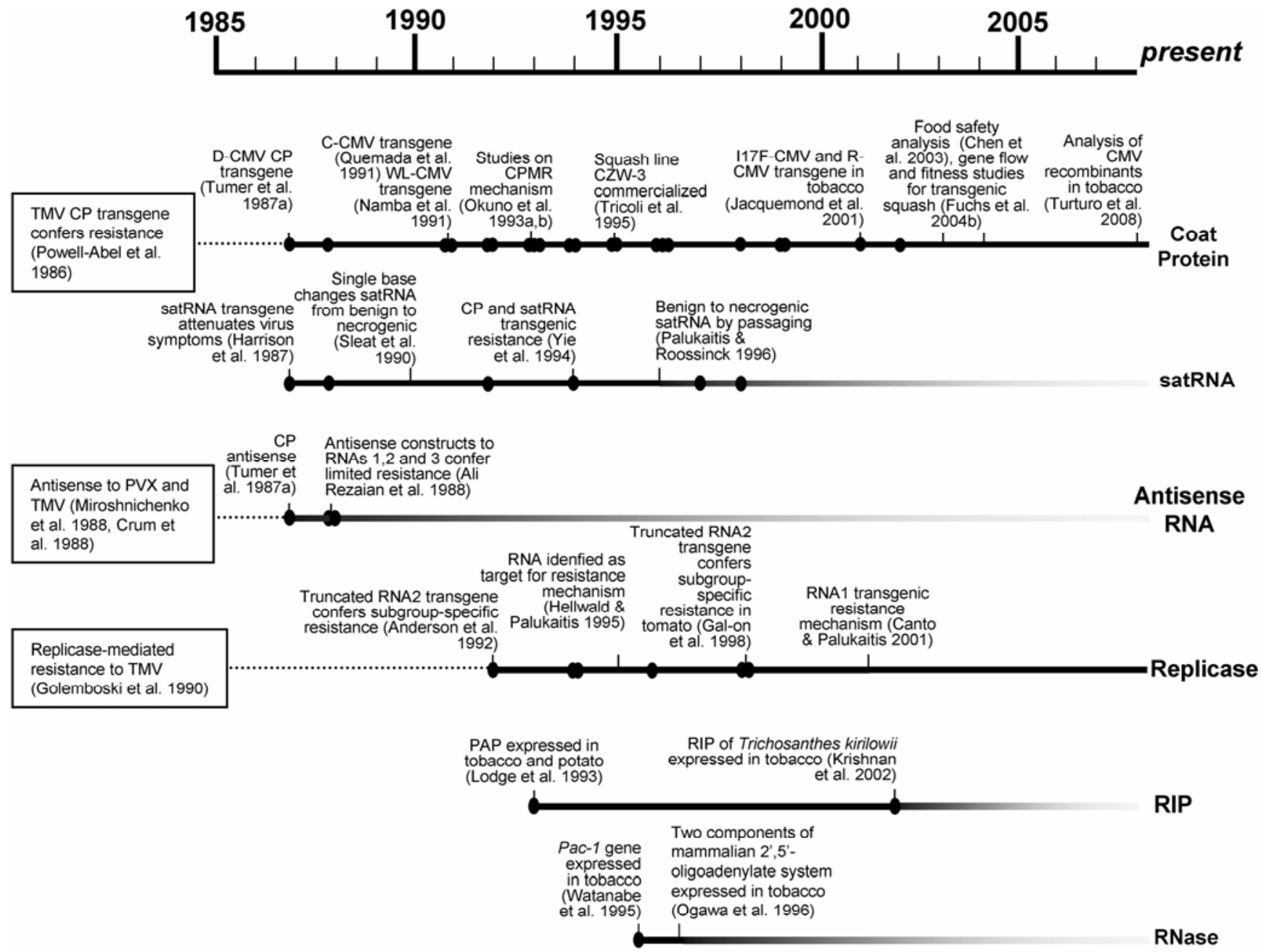

Some resistance obtained in plants containing transgene with ribozyme in RNA1 and 2

Ribozyme incorporated into antisense construct provides no advantage to TMV resistance (de Feyter et al. 1996) of CMV (Kwon et al. 1997)

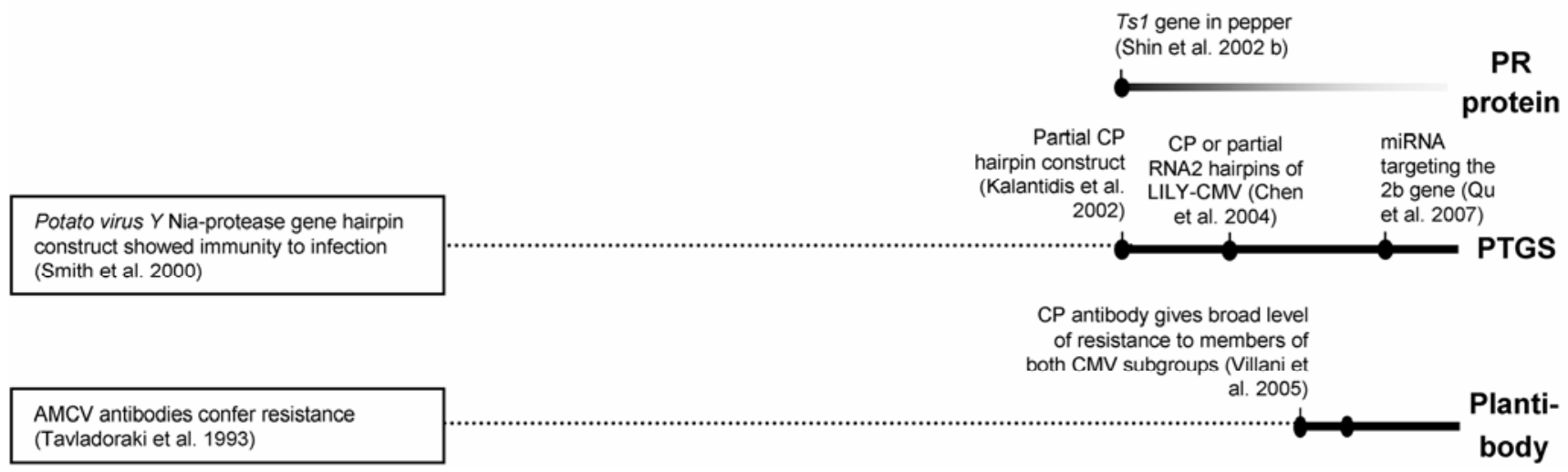

Fig. 1. Timeline of different techniques used to produce transgenic plants resistant to Cucumber mosaic virus (CMV). Boxes on the left contain examples of the first practical applications of each technique for plant virus resistance. The black dots in each line represent reports in which the level of resistance of the transformed plants was analyzed. The articles cited are considered of particular significance in the development of the technique. TMV = Tobacco mosaic virus, $\mathrm{CP}=$ coat protein, $\mathrm{CPMR}=\mathrm{CP}$-mediated resistance, satRNA = satellite RNA, PR = pathogenesis related, $\mathrm{PTGS}=$ post-transcriptional gene silencing, $\mathrm{AMCV}=$ Artichoke mottle crinkle virus, $\mathrm{RIP}=$ ribosome inactivating protein. 
tance is mediated by post-transcriptional gene silencing (PTGS). However, the first mechanism proposed to explain CPMR was that it acted at a protein level. This was based on the observation that, in the case of CPMR to TMV, resistance was expressed when plants were inoculated with virions but not when inoculated with viral RNA or even with partially stripped virions, suggesting a mechanism at an early stage during infection, possibly by inhibition of uncoating of virus particles (Asurmendi et al. 2007; Bendahmane et al. 2007; Osbourn et al. 1990; Register and Beachy 1988; Wu et al. 1990). However, since the first description of transgenes conferring resistance via a mechanism related to PTGS (Lindbo et al. 1993), there has been a tendency to assume that the latter is the predominant mechanism for resistance to viruses other than TMV. In this case, the transgene mRNA serves as the template for synthesis of double-stranded RNA, which is then acted upon by Dicer-like enzymes responsible for generating small interfering (si)RNA. The virus-specific siRNAs then are loaded into the effector RNA induced silencing complex (Ding and Voinnet 2007). Diagnostic features of PTGS-mediated resistance are i) the presence of siRNAs, ii) the observation of strong resistance in plants in which neither transgene mRNA nor the corresponding protein are observed, and iii) that it can be obtained with transgenes encoding untranslatable mRNAs. However, it should be noted that, in the case of tospoviruses, resistance can be conferred by both protein- and PTGS-mediated mechanisms (Pang et al. 1994). Therefore, perhaps more generally, in a given virus-resistant plant line, resistance can be due to complementary action of more than one mechanism.

\section{CP-mediated resistance to CMV.}

As mentioned above, CPMR to CMV was reported in 1987, the year following the first description of CPMR. It should be noted that CMV CP antisense genes also were tested; however, because they conferred little or no protection, this strategy has not been explored further. As for other viruses, CPMR has been used widely to create CMV resistance, with positive results reported with six plant species (tobacco, cucumber, tomato, melon, squash, and pepper) in more than 20 publications (Table 1). In the earliest work, transformation of tobacco plants with a gene encoding the CP of D-CMV (subgroup I) resulted in strong reduction in the incidence of virus infection in both inoculated and systemically infected leaves when inoculated with D-CMV (Cuozzo et al. 1988; Tumer et al. 1987a). Using a similar methodology, Quemada and associates (1991) obtained three tobacco lines expressing a CP gene from C-CMV (subgroup I). When challenged with either C-CMV, the severe subgroup I Chi-CMV, or the subgroup II WL-CMV, two lines were more resistant to the more homologous strains. Nevertheless, the fact that two lines were also moderately resistant to the more divergent subgroup II strain suggested that there was no consistent positive correlation between the level of amino acid sequence identity between the transgene and the challenging virus and the level of protection conferred. Following up on the above study, Namba and associates (1991) used the CP gene of WL-CMV (subgroup II) to obtain a higher level of resistance to all three strains tested by Quemada and associates (1991). Encouraged by these results, several groups then used the same WL-CMV CP construct in other crops, with some-

Table 1. Reports of plants transgenic for Cucumber mosaic virus (CMV) coat protein (CP) where resistance was analyzed

\begin{tabular}{|c|c|c|c|c|c|}
\hline Reference & $\begin{array}{l}\text { Donor virus strain } \\
\text { (subgroup) transgene }\end{array}$ & $\begin{array}{l}\text { Host } \\
\text { species }\end{array}$ & $\begin{array}{c}\text { Challenging virus strain } \\
\text { (subgroup) }\end{array}$ & Inoculum $^{\mathrm{a}}$ & $\begin{array}{c}\text { Degree of } \\
\text { resistance }(\%)^{b}\end{array}$ \\
\hline Tumer et al. $1987 \mathrm{a}$ & $\mathrm{D}(\mathrm{I})$ & Tobacco & $\mathrm{D}(\mathrm{I})$ & Virions $25 \mu \mathrm{g} / \mathrm{ml}$ & 40 to 90 \\
\hline Cuozzo et al. 1988 & $\mathrm{D}(\mathrm{I})$ & Tobacco & $\mathrm{C}(\mathrm{I})$ & Virions $25 \mu \mathrm{g} / \mathrm{ml}$ & 0 to 100 \\
\hline Namba et al. 1991 & WL (II) & Tobacco & $\begin{array}{l}\text { C } \\
\text { Chi (I) } \\
\text { WL (II) }\end{array}$ & Sap & $\begin{array}{l}100 \\
65 \text { to } 85 \\
75 \text { to } 85\end{array}$ \\
\hline Quemada et al. 1991 & $\mathrm{C}(\mathrm{I})$ & Tobacco & $\begin{array}{l}\text { C } \\
\text { Chi (I) } \\
\text { WL (II) }\end{array}$ & Sap or aphids & $\begin{array}{l}100 \\
85 \\
55\end{array}$ \\
\hline Gonsalves et al. 1992 & $\mathrm{C}(\mathrm{I})$ & Cucumber & Cat (I), NI & Sap, NI & 86 to 100 \\
\hline Yie et al. 1992 & $\mathrm{O}(\mathrm{I})$ & Tobacco & $\mathrm{B}$ & Virions $25 \mu \mathrm{g} / \mathrm{ml}$ & 40 \\
\hline Nakajima et al. 1993 & $\mathrm{O}(\mathrm{I})$ & Tobacco & $\mathrm{O}, \mathrm{Y}(\mathrm{I}), \mathrm{TAV}^{\mathrm{c}}$ & Virions 1 to $50 \mu \mathrm{g} / \mathrm{ml}$ & 0 to 100 \\
\hline Okuno et al. 1993a,b & $\mathrm{Y}(\mathrm{I})$ & Tobacco & Y, O (I), Pepo, CS, FT & Virions, RNA 1 to $100 \mu \mathrm{g} / \mathrm{ml}$ & 0 to 100 \\
\hline Gonsalves et al. 1994 & WL (II) & Melon & Fny (I) & Sap & Delay \\
\hline Xue et al. 1994 & WL (II) & Tomato & $\begin{array}{l}\text { Chi (I) } \\
\text { WL (II) }\end{array}$ & Sap & $\begin{array}{l}80 \text { to } 100 \\
91 \text { to } 100\end{array}$ \\
\hline Provvidenti and Gonsalves 1995 & WL (II) & Tomato & $\begin{array}{l}9 \text { strains (I) } \\
3 \text { strains (II) }\end{array}$ & Sap & 100 \\
\hline Tricoli et al. 1995 & $\mathrm{C}(\mathrm{I})$ & Squash & $\mathrm{C}(\mathrm{I})$ & Sap & 92 to 100 \\
\hline Gielen et al. 1996 & $\mathrm{ZU}(\mathrm{I})$ & Tomato & $\begin{array}{l}\text { CMV-I17F (I), CMV-ARN5 } \\
\text { (I), CMV-A (II), NI }\end{array}$ & Sap & 50 to 100 \\
\hline & & & & NI & 45 to 100 \\
\hline Fuchs and Provvidenti 1996 & WL (II) & Tomato & Fny (I) & Sap, NI & 100 \\
\hline Rizos et al. 1996 & CP91/367, SB91/366 (I) & Tobacco & $\begin{array}{l}\text { CP91/367, SB91/366 (I) } \\
\text { LU91/166 (II) }\end{array}$ & Sap & $\begin{array}{l}0 \text { to } 66 \\
37 \text { to } 83\end{array}$ \\
\hline Singh et al. 1998 & $\mathrm{C}(\mathrm{I})$ & Tobacco & $\begin{array}{l}3 \text { strains (I) } \\
5 \text { strains (II) }\end{array}$ & $\begin{array}{l}\text { Sap } \\
\text { Graft }\end{array}$ & $\begin{array}{l}0 \text { to } 80 \\
0 \text { to } 80\end{array}$ \\
\hline Kaniewski et al. 1999 & D, 22 (I), PG (II) & Tomato & 22 (I), PG (II) & Virions $100 \mu \mathrm{g} / \mathrm{ml}$ or aphids & 70 to 100 \\
\hline Tomassoli et al. 1999 & D, 22 (I), PG (II) & Tomato & $22(\mathrm{I}), \mathrm{NI}$ & NI & 0 to 100 \\
\hline Jacquemond et al. 2001 & $\mathrm{R}$ (II) & Tobacco & $\mathrm{R}(\mathrm{II})$ & $\begin{array}{l}\text { Virions } 5 \text { to } 10 \mu \mathrm{g} / \mathrm{ml} \text {, } \\
\text { aphids, RNA } 5 \text { to } 10 \mu \mathrm{g} / \mathrm{ml}\end{array}$ & Recovery \\
\hline Shin et al. 2002a & Kor & Pepper & Kor & $\mathrm{ND}$ & 10 to 90 \\
\hline
\end{tabular}

${ }^{\mathrm{a}} \mathrm{NI}=$ natural infection in the field and $\mathrm{ND}=$ no data.

${ }^{\mathrm{b}}$ Percentage of the number of noninfected plants over total number of inoculated plants.

${ }^{\mathrm{c}}$ In the original paper, Tomato aspermy virus (TAV) is reported as Chrysanthemum mild mottle cucumovirus (CMMV). 
what varying degrees of success. For example, the WL-CMV $\mathrm{CP}$ construct conferred a broad resistance to a large number of CMV subgroup I and II strains in tomato (Fuchs et al. 1996; Provvidenti and Gonsalves 1995; Xue et al. 1994) and cucumber (Gonsalves et al. 1992), but only weak protection in melon (Gonsalves et al. 1994). In squash, on the other hand, the efficacy of the C-CMV CP gene was demonstrated by the creation of the triply resistant line CZW-3, in which expression of the three corresponding $\mathrm{CP}$ genes confers resistance not only to CMV but also to Zucchini yellow mosaic virus and Watermelon mosaic virus (Quemada 1998; Tricoli et al. 1995). In 1996, line CZW-3 became the second VRTP to be deregulated for commercial use in the United States. In the ensuing years, other transgene constructs designed to induce CPMR to CMV have been introduced into a number of plant species (Table 1), some of which have been further tested in both the laboratory and the field with the aim of assessing levels of resistance (Fuchs et al. 1996; Gielen et al. 1996; Jacquemond et al. 2001; Tricoli et al. 1995), the fitness of the virus-resistant crop plants (Fuchs et al. 2004b; Gonsalves et al. 1992; Tomassoli et al. 1999), the risks that could be mediated by gene flow to wild populations (Fuchs et al. 2004a), potential impacts of messenger or viral RNA recombination (Pierrugues et al. 2007; Turturo et al. 2008), and food safety (Chen et al. 2003).

In conclusion, CPMR has been shown to be a useful tool in the development of new CMV-resistant plants, although different qualities of resistance were observed depending on the donor strain, the challenging strains, and the plant species. Indeed, considering the number of publications, it is remarkable that it is still impossible to predict which kind of $\mathrm{CP}$ gene construct, from which subgroup, will be most effective. As mentioned above, the C-CMV CP gene gave quite different levels of resistance in different host plants. When very similar $\mathrm{CP}$ transgenes were created from nearly identical subgroup I donor strains, in some cases, high levels of resistance were observed in tobacco, as with C- or D-CMV, whereas, in others, there was absolutely no resistance, such as in the tobacco lines expressing high levels of CP of I17F-CMV (Jacquemond et al. 2001). The range of resistances obtained also can vary from complete susceptibility to extreme resistance, even in lines obtained with the same transgene (Table 1). Therefore, in order to have a clearer picture of the effectiveness of any transgene in conferring resistance, it is essential to screen a large number of lines. In an attempt to bring some clarity to this rather confusing situation, in the following section we will discuss the current state of knowledge regarding the mechanisms of CPMR to CMV.

\section{Mechanisms of CPMR to CMV.}

Regarding CMV, there are no cases described of resistance in the absence of transgene mRNA or CP (Cuozzo et al. 1988; Jacquemond et al. 2001; Namba et al. 1991; Okuno et al. 1993a and b; Quemada et al. 1991; Tricoli et al. 1995; Tumer et al. 1987a). Also, in many but not all cases, the most resistant lines were those that accumulated the highest levels of $\mathrm{CP}$, which would be expected for protein-mediated resistance (Kaniewski et al. 1999; Okuno et al. 1993a; Shin et al. 2002b). In addition, considering the level of CP gene sequence identity between subgroups I and II (approximately 70\%), it is unlikely that PTGS could be involved in resistance to subgroup II strains observed in plants expressing a CP gene from a subgroup I strain, and vice versa (Namba et al. 1991; Provvidenti and Gonsalves 1995; Quemada et al. 1991; Xue et al. 1994).

Two groups have clearly demonstrated cases of CPMR to CMV that was not mediated by PTGS. Jacquemond and associates (2001) described plants expressing the CP of R-CMV (subgroup II), which displayed resistance by recovery. If resistance in these plants was due to PTGS, the transgene-derived viral RNAs also would have been targeted for degradation along with the RNA of the challenging virus. However, they showed that the level of the transgene mRNA remained constant or increased in the inoculated resistant plants, which is clearly incompatible with a PTGS-based mechanism (Jacquemond et al. 2001). Another interesting study was reported by Okuno and associates (1993a and b). They showed that plants expressing a Y-CMV CP gene were resistant to Y-CMV infection when challenged with either virions or viral RNAs, whereas protoplasts were resistant to virions but susceptible to RNA inoculation (Okuno et al. 1993a and b). Thus, this situation is different from the protein-mediated resistance in plants expressing a TMV CP gene, which are resistant to inoculation by virions but susceptible when inoculated with RNA or partially stripped virions (Register and Beachy 1988). Significantly, the resistance described by Okuno and associates (1993b) was also temperature sensitive, being markedly reduced above $30^{\circ} \mathrm{C}$, which coincided with a reduction in transgene-derived CP levels but not in RNA levels, as also has been shown for TMV (Nejidat and Beachy 1989). The TMV results suggest that the $\mathrm{CP}$ interferes with the very earliest steps of infection (i.e., the initial decapsidation) whereas, with CMV, the results of Okuno and associates (1993a and b) suggest a blockage at a somewhat later step in the infection cycle. They proposed that the transgene-derived CP blocked interaction between the viral RNA and the viral $\mathrm{CP}$, thereby inhibiting its transit through the plant (Okuno et al. 1993a and b).

Such observations concur well with the CMV CP's essential role in cell-to-cell and systemic CMV movement (Canto et al. 1997; Kaplan and Palukaitis 1998; Taliansky and Garcia-Arenal 1995). However, interference with CMV movement does not take into account the observations with protoplasts (Okuno et al. 1993a and b) which, as mentioned above, were resistant to virions but susceptible to RNA inoculation; this suggests at least some contribution related to decapsidation, as has been described for TMV. In fact, there also is evidence that interference with movement also contributes-albeit in a minor way-to CPMR to TMV (Wisnieswski et al. 1990). Therefore, the apparent differences in mechanism between CPMR to TMV and to CMV may, in fact, reflect differences in the relative contributions of the two mechanisms. For TMV, it has been shown clearly that interference with decapsidation depends on rather subtle differences in protein interactions (Bendahmane et al. 2007); therefore, this could well explain the strain-specific differences in CPMR to CMV. Similarly, considering that movement of CMV requires interactions between the $\mathrm{CP}$, viral movement protein, and host proteins, it is to be expected that, in addition, this type of CPMR would be highly sensitive to differences in the sequence of the pertinent host proteins.

\section{Replicase-mediated resistance to $\mathrm{CMV}$.}

In 1990, Zaitlin's group demonstrated in serendipitous fashion that the TMV gene encoding the putative 54-kDa protein when transferred into tobacco conferred resistance to TMV (Golemboski et al. 1990). The resistance was overcome neither by high inoculum loads nor when challenged with RNA. Two years later, the same lab showed that a similar approach could be developed for CMV. In this case, the RNA 2 transgene was engineered so that the 2 a gene (of subgroup IA Fny-CMV) was truncated by some $30 \%$ by internally deleting a region surrounding the highly conserved GDD motif (Anderson et al. 1992) (Table 2). In the resulting resistant transgenic tobacco lines, both the defective RNA transcript (Anderson et al. 1992) and protein were detectable (Carr et al., 1994). The resistance obtained was durable, even when challenged with high inoculum doses of either virion or RNA, but was overcome by three 
subgroup IB strains and four subgroup II strains when inoculated either mechanically or by aphids (Zaitlin et al. 1994). This same construct also was shown to be effective in conferring resistance in tomato against both subgroup IA and IB strains (Gal-On et al. 1998). In another study, plants transgenic for RNA 1 of Fny-CMV were able to complement accumulation of RNAs 2 and 3 and were susceptible to virus infection. Yet the $R_{3}$ generation progeny of one line that showed variable susceptibility was found to be resistant, with a marked decrease in the levels of viral RNA 1 in the inoculated leaf (Canto and Palukaitis 1998; Gal-On et al. 1998).

\section{Mechanisms of replicase-mediated resistance.}

Unlike for TMV replicase-mediated resistance, where it was shown that expression of the 54-kDa protein was necessary to induce resistance (Carr et al. 1992), for CMV replicase-mediated resistance, the question of whether the effector is a protein or nucleic acid has not been answered so conclusively. Most of the work carried out to determine the mechanism has been on the truncated CMV 2a protein (Anderson et al. 1992). When these plants were inoculated with high virus concentrations, local chlorotic lesions were observed in the inoculated leaves of highly resistant lines which, upon analysis, were shown to contain very low levels of the infecting viral replicase, $\mathrm{CP}$, and RNA (Carr et al. 1994). There was no systemic infection, because the virus was blocked at the bundle sheath or vascular parenchyma and companion cell interface (Wintermantel et al. 1997). In microinjection assays, the movement component to the resistance was shown to be due to an inability of the viral movement protein to both potentiate trafficking of viral RNA and increase the size exclusion limit of plasmodesmata (Nguyen et al. 1996). Contrary to these results, a study using a viral construct tagged with green fluorescent protein found no such restriction in virus cell-to-cell movement (Canto and Palukaitis 1999). Analysis of systemic viral movement showed that transgenic resistant scions grafted onto nontransgenic rootstocks infected with Fny-CMV did become infected, but with much reduced levels of viral RNA (Wintermantel et al. 1997), comparable with those found in transgenic protoplasts (Carr et al. 1994). This is in contrast to grafting experiments using the same transgene construct in tomato, where virions were unable to move into the transgenic scion (Gal-On et al. 1998). In protoplasts, accumulation of viral RNAs was up to 70-fold less than in nontransgenic plants, pointing to a resistance mechanism that worked primarily at the cellular level by suppressing virus replication but, to lesser extent, by impeding systemic movement (Carr et al. 1994). By using a pseudorecombinant between Fny-CMV and a subgroup I strains that overcame resistance, K-CMV (Zaitlin et al. 1994), the breakdown of resistance was shown to map to RNA 2, of which there is $92.4 \%$ identity between the two strains (Hellwald and Palukaitis 1994, 1995). Chimeric RNA 2 constructs generated between Fny- and K-CMV, and subsequently modified to alter nucleotide but not amino acid sequences, indicated that RNA is the target for the resistance mechanism (Hellwald and Palukaitis 1995). Nevertheless, attempts to identify the elicitor of resistance tend to point to a protein rather than RNA model; Wintermantel and Zaitlin (2000) found only $1.6 \%$ resistant

Table 2. Reports of plants transgenic for Cucumber mosaic virus (CMV) replicase component (either RNA 1, RNA 2, or both)

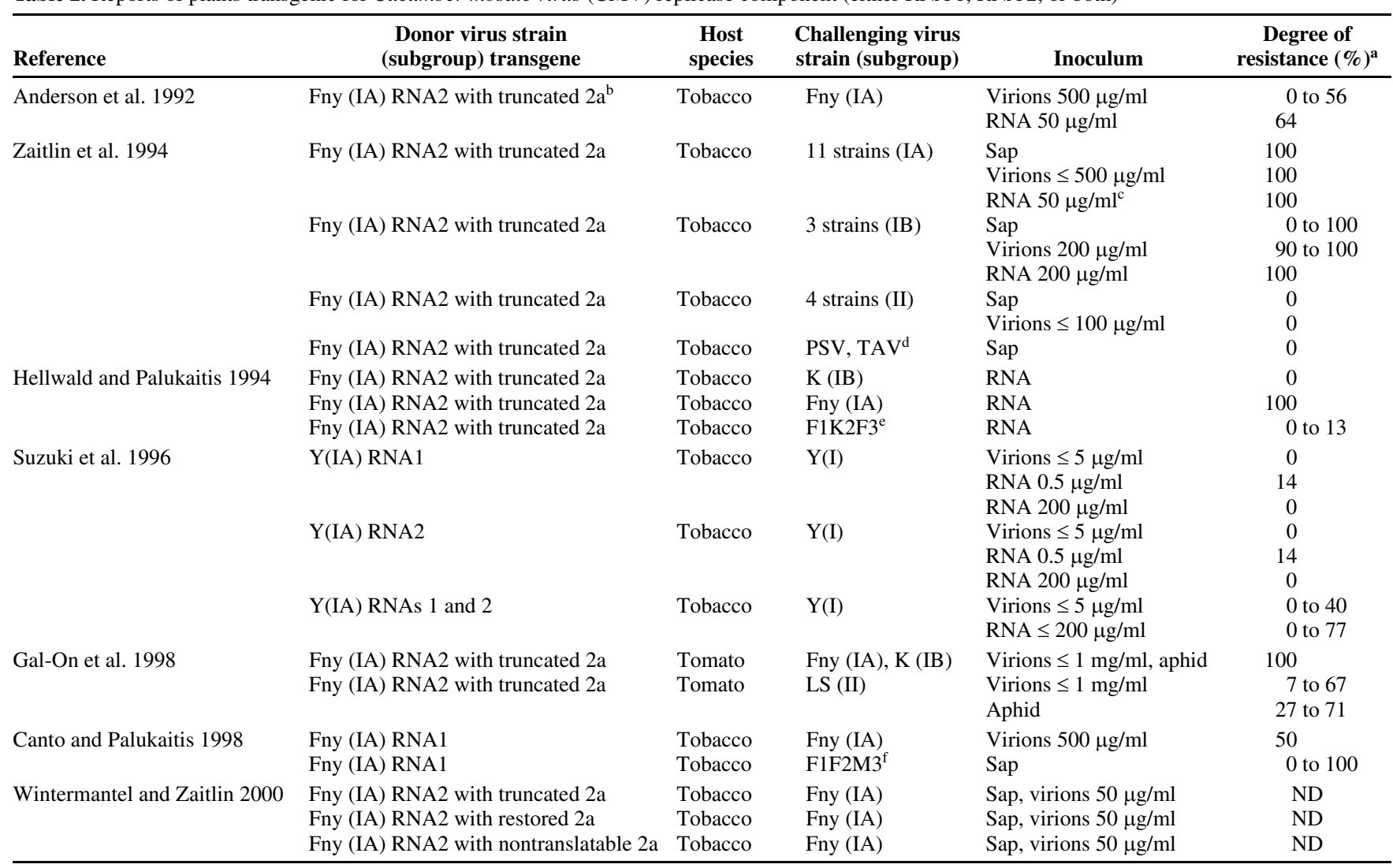

${ }^{a}$ Percentage of the number of noninfected plants over total number of inoculated plants. ND = no data.

b Data shown for original lines 1-2 and 1-8 and subsequent generations (Anderson et al. 1992).

c Some strains were inoculated as either sap or virions or RNA.

d Peanut stunt virus and Tomato aspermy virus.

e Pseudorecombinant containing RNAs 1 and 3 from Fny-CMV (I) and RNA2 from K-CMV (I).

${ }^{\mathrm{f}}$ Pseudorecombinant containing RNAs 1 and 2 from Fny-CMV (I) and RNA3 from M-CMV (II). 
lines with plants transformed with a noncoding CMV RNA 2 construct, compared with 6.6 and $11.9 \%$ in plants transformed with constructs containing truncated or full-length gene products, respectively.

An additional mechanism has been proposed for tobacco plants transgenic for full-length RNAs 1 and 2 of Y-CMV, whereby an excess in the levels of both RNAs causes a reallocation of CP away from RNAs 3 and 4 and results in the latter's failure to be effectively encapsidated (Suzuki et al. 1996). Curiously, in the same study, plants containing single transgenes of RNA 1 or RNA 2 were as susceptible to infection as nontransgenic plants. In $\mathrm{R}_{3}$ plants transgenic for RNA 1 , resistance was obtained whereby no systemic viral infection occurred. However, in these same plants, it was found that noninoculated leaves not only could complement the replication of RNAs 2 and 3 but also were susceptible to virus infection; results which exclude a systemically acquired PTGSmediated resistance mechanism (Canto and Palukaitis 1998). Further analysis of the potential mechanisms of resistance showed, similar to that for RNA 2, specific homologous suppression of accumulation of viral RNA at the cellular level and a restriction in virus long-distance movement (Canto and Palukaitis 2001). Therefore, it appears that, despite the absence of data regarding siRNAs, although PTGS may play a secondary role, there is no clear evidence that it is the primary mechanism of CMV replicase-mediated resistance. In particular, in the plants expressing a modified 2 a protein, it is more probable that resistance is conferred essentially by the protein acting as a dominant negative mutant.

\section{Resistance to CMV mediated by PTGS.}

It had been shown by Wang and associates (2000) that enhanced PTGS-mediated resistance could be obtained with an inverted-repeat transgene encoding a hairpin RNA. In the first clear demonstration of PTGS-mediated resistance to CMV, Kalantidis and associates (2002) transformed tobacco with a construct containing an inverted-repeat of a 747-bp fragment of the CP of CMV and a 1,445-bp spacer, in both a sense and antisense orientation. Their results showed that lines with two or more transgenes were more likely to become resistant, whereas levels of siRNAs, which increased with increasing temperature $\left(25\right.$ to $\left.32^{\circ} \mathrm{C}\right)$, correlated positively to levels of

Table 3. Reports of transgenic plants produced for Cucumber mosaic virus (CMV) resistance using alternative strategies

\begin{tabular}{|c|c|c|c|c|c|}
\hline Strategy, reference & Transgene (donor) & Host species & $\begin{array}{l}\text { Challenging pathogen } \\
{(\text { virus subgroup })^{\mathrm{a}}}^{\text {(virus }}\end{array}$ & CMV inoculum & $\begin{array}{l}\text { CMV degree of } \\
\text { resistance }(\%)^{b}\end{array}$ \\
\hline \multicolumn{6}{|l|}{ RNA satellites } \\
\hline Harrison et al. 1987 & Sat-I17N & Tobacco & CMV-K (I) & Sap & 80 to $95^{c}$ \\
\hline Jacquemond et al. 1988 & Sat-I17N & Tobacco & CMV-I17F (I) & Sap & 70 to $74^{d}$ \\
\hline Yie et al. 1992 & $\begin{array}{l}\text { Sat-RNA1 } \\
\text { Sat-RNA1 + CP (CMV-O) }\end{array}$ & Tobacco & CMV-B (I) & Virions $25-50 \mu \mathrm{g} / \mathrm{ml}$ & $\begin{array}{r}0 \text { to } 20 \\
70 \text { to } 75\end{array}$ \\
\hline Peña et al. 1994 & Sat-S & Tobacco & CMV-1 & Virions $50 \mu \mathrm{g} / \mathrm{ml}$ & 0 to 75 \\
\hline Kim et al. 1997 & Sat-I17N & Pepper & CMV-Y (I), CMV-Kor (I) & Virions $10 \mu \mathrm{g} / \mathrm{ml}$ & 70 to $80^{e}$ \\
\hline Stommel et al. 1998 & Sat-S & Tomato & CMV-1 & Virions $20 \mu \mathrm{g} / \mathrm{ml}$ & 40 to $84^{\mathrm{f}}$ \\
\hline \multicolumn{6}{|l|}{ Antisense RNAs } \\
\hline Tumer et al. 1987a & (CMV-D) & Tobacco & CMV-D (I) & $\begin{array}{l}\text { Virions } 1 \mu \mathrm{g} / \mathrm{ml} \\
\text { Virions } 15 \mu \mathrm{g} / \mathrm{ml}\end{array}$ & $\begin{array}{r}60 \\
0\end{array}$ \\
\hline Ali Rezaian et al. 1988 & (CMV-Q) & Tobacco & CMV-Q (II) & Virions $0.5 \approx 50 \mu \mathrm{g} / \mathrm{ml}$ & 0 \\
\hline Cuozzo et al. 1988 & (CMV-D) & Tobacco & CMV-C (I) & $\begin{array}{l}\text { Virions } 1 \mu \mathrm{g} / \mathrm{ml} \\
\text { Virions } 5-25 \mu \mathrm{g} / \mathrm{ml}\end{array}$ & $\begin{array}{r}\approx 70 \\
0\end{array}$ \\
\hline \multicolumn{6}{|l|}{$R I P$} \\
\hline Lodge et al. 1993 & PAP (Phytolacca americana) & Tobacco, potato & CMV, PVY, PVX & Virions $50 \mu \mathrm{g} / \mathrm{ml}$ & $67^{\mathrm{g}}$ \\
\hline Krishnan et al. 2002 & TCS (Trichosanthes kirilowii) & Tobacco & CMV, TMV & Sap & $\mathrm{DS}^{\mathrm{g}}$ \\
\hline \multicolumn{6}{|l|}{ Ribonucleases } \\
\hline Watanabe et al. 1995 & pacl (Yeast) & Tobacco & CMV-Y (I), TMV, PVY & Virions $10 \mu \mathrm{g} / \mathrm{ml}$ & $\mathrm{DS}^{\mathrm{g}}$ \\
\hline Ogawa et al. 1996 & 2-5Aase + RNaseL & Tobacco & CMV-Y (I) & Virions $15 \mu \mathrm{g} / \mathrm{ml}$ & ND \\
\hline Honda et al. 2003 & 2-5Aase + RnaseL & Tobacco & CMV-Y (I) & Virions $100 \mu \mathrm{g} / \mathrm{ml}$ & ND \\
\hline \multicolumn{6}{|l|}{ Enhancement of $H R / S A R$} \\
\hline Ogawa et al. 1996 & 2-5Aase + RNaseL & Tobacco & CMV-Y (I) & Virions $15 \mu \mathrm{g} / \mathrm{ml}$ & ND \\
\hline Shin et al. $2002 b$ & Tsil (Tobacco) & Pepper & $\begin{array}{l}\text { CMV-Y, PMMV, } 1 \text { bacteria, } \\
1 \text { oomycete }\end{array}$ & Sap & $22^{\mathrm{c}, \mathrm{g}}$ \\
\hline Honda et al. 2003 & 2-5Aase + RnaseL & Tobacco & CMV-Y (I) & Virions $100 \mu \mathrm{g} / \mathrm{ml}$ & ND \\
\hline \multicolumn{6}{|l|}{ Hammerhead ribozyme } \\
\hline Kwon et al. 1997 & $\begin{array}{l}\text { Conserved sequences of } \\
\text { RNA1 and } 2 \text { of CMV-Y }\end{array}$ & Tobacco & CMV-Y (I) & Virions $10 \mu \mathrm{g} / \mathrm{ml}$ & 10 to 85 \\
\hline \multicolumn{6}{|l|}{ Plantibodies } \\
\hline Villani et al. 2005 & ScFv antibodies ${ }^{\mathrm{h}}$ & Tomato & CMV-F100 (I), CMV-CAR (II) & Sap & $\approx 50(\mathrm{CMV}-\mathrm{F} 100)$ \\
\hline Aebig et al. 2006 & ScFv antibodies ${ }^{\mathrm{h}}$ & Tobacco & CMV & ND & $\mathrm{DS}^{\mathrm{i}}$ \\
\hline $\begin{array}{l}\text { a PVY = Potato virus } Y, \mathrm{P} \\
\text { oomycete = Phytophtho } \\
\text { b Percentage of number of } \\
{ }^{\text {c }} \text { Decrease in coat protein } \\
{ }^{d} \text { Average reduction in the } \\
\text { e Amount of local lesions } \\
{ }^{\text {f }} \text { Calculated on marketabl } \\
\text { g Referred to CMV. } \\
{ }^{\text {h }} \text { Single-chain variable fra } \\
{ }^{i} \text { Lost in subsequent gene }\end{array}$ & $\begin{array}{l}\mathrm{X}=\text { Potato virus } X, \mathrm{TMV}=T \\
\text { capsici. } \\
\text { toninfected plants over total nu } \\
\text { mount. } \\
\text { oat protein yield in leaves of tr } \\
\text { Chenopodium quinoa. } \\
\text { yield. } \\
\text { ments. } \\
\text { tions. }\end{array}$ & $\begin{array}{l}\text { bacco mosaic viru } \\
\text { nber of inoculated } \\
\text { nsgenic plant com }\end{array}$ & $\begin{array}{l}\text { PMMV = Pepper mild mottle vi } \\
\text { lants. ND = no data and DS = del } \\
\text { ared with nontransformed. }\end{array}$ & $\begin{array}{l}\text { irus, bacteria = Xanthor } \\
\text { layed symptoms. }\end{array}$ & nas campestris, anc \\
\hline
\end{tabular}


resistance, though levels of hairpin transcript were variable (Kalantidis et al. 2002). More recently, using inverted-repeat CP or RNA 2 sequences of LILY-CMV (subgroup I) separated by an Arabidopsis actin 2 intron spacer, $\mathrm{R}_{1}$ transgenic progeny were produced that were $100 \%$ resistant (Chen et al. 2004). Comparing this with single constructs (without inverted repeats), it was found that, whereas $20 \%$ of the RNA $2 \mathrm{R}_{1}$ progeny were resistant, no $\mathrm{CP} \mathrm{R}_{1}$ lines were resistant. All resistant plants produced readily detectable amounts of siRNAs specific to LILY-CMV, the immunity observed being completely overcome by a subgroup II strain (Chen et al. 2004). Because the CMV $2 \mathrm{~b}$ gene is a potent suppressor of PTGS, the absence of PTGSmediated resistance in $\mathrm{CP}$ - and perhaps also replicase-constructs may be attributed to activity of the $2 \mathrm{~b}$ gene.

A more recent attempt to confer resistance to CMV using a small RNA pathway focused on transgenic artificial microRNAs (miRNA) that targeted a 21-nucleotide sequence within the $2 \mathrm{~b}$ gene by using an inverted-repeat construct (Qu et al. 2007). When expressed in Arabidopsis, 64\% of the plants were resistant to the target strain. This work, along with that of Niu and associates (2006), opens up the possibility of developing even smaller transgenes that target specific pathways of the small RNA regulatory network.

\section{CMV satellite-RNA-mediated resistance.}

The discovery of CMV satellite RNAs (satRNAs) in the 1970s came about because of their involvement in various outbreaks of lethal necrosis in tomato in southern Europe (Simon et al. 2004). In spite of this, subsequent work showed that the majority of CMV satRNAs attenuate rather than increase symptoms, and even those that cause lethal necrosis in tomato cause attenuation in tobacco and other species. The ability of satRNAs to attenuate CMV symptoms has been used to protect plants from severe symptoms by preinoculating plants with satRNA prior to infection with CMV (Jacquemond 1982; Montasser et al. 1998; Sayama et al. 1993), a technique that was developed for commercial use in both Japan (Sayama et al. 1993) and China (Stommel et al. 1998) (Table 3). Similarly, plants transgenic for CMV satRNA developed attenuated symptoms in tobacco (Harrison et al. 1987; Jacquemond et al. 1988; Yie et al. 1992), petunia (Kim et al. 1995), pepper (Kim et al. 1997), and tomato (McGarvey et al. 1994; Stommel et al. 1998). However, concerns were voiced quite early about the overall safety of such an approach on account of the necrogenic properties of certain satRNAs. These concerns were reinforced when it became apparent that only very minor sequence differences distinguish necrogenic from benign satRNAs (Jacquemond and Tepfer 1998). In addition, in passage experiments with tobacco it was found that not only could a shift from benign to necrogenic occur spontaneously but also that the latter phenotype could rapidly dominate the satRNA population within the host (Palukaitis and Roossinck 1996). With such a potential risk, albeit laboratory based, the use of transgenic satRNAs has, for all intents and purposes, been abandoned (Jacquemond and Tepfer 1998).

\section{Transgenes based on nonviral sources of resistance.}

Besides the major strategies described above, which are based on pathogen-derived resistance, some effort also has been devoted to resistance derived from nonviral sources. For CMV, these include ribosome inactivating proteins, ribonucleases, ribozymes, pathogenesis-related proteins, and plant expressing antibodies directed against viral proteins (Table 3 ). All of these strategies were covered in sufficient detail in a recent review (Prins et al. 2008) and, thus, will not be described here, particularly because there are no $\mathrm{CMV}$-specific features of these types of resistance. Although some of them possibly could lead to broad-range resistance to different viruses, most also have seri- ous flaws, such as toxicity (e.g., ribosomal inactivating proteins) or induction of undesirable morphological defects (e.g., ribonucleases). The major exception to this is the use of antibodies directed against viral proteins, which can confer strong resistance to the target virus, although the breadth and durability of antibody-mediated resistance will need to be fully investigated.

\section{Concluding remarks.}

As we have seen from this survey, virus-derived transgenes continue to be the favored means for conferring virus resistance. However, from the very beginning, transgenic plants expressing viral sequences have been used for two purposes; not only do they often confer virus resistance but they also are a powerful tool for understanding plant-virus interactions. However, in spite of the number of publications that have appeared, we still have a limited understanding of the mechanism or mechanisms of resistance involved, except when resistance is PTGS mediated. Considering the numerous viruses that have been targeted by $\mathrm{CP}$ transgenes, it is striking that only for TMV has proteinmediated resistance been well characterized. In the case of plants expressing a CMV CP gene, there is an apparent lack of evidence for PTGS-mediated resistance and some suggestion that interference with virus movement is primarily involved. Unfortunately, this leaves us today in a situation where creating VRTP remains highly empirical. This problem can be overcome only through a clearer understanding of at least two things: how modifications in CMV-host interactions in VRTP lead to resistance and why a given transgene confers different degrees of resistance in different plant species.

From a biotechnological point of view, it is highly desirable to create CMV resistance with the following characteristics: efficacy against all strains of the target virus and durability in the field, while incorporating all the features that will minimize biosafety concerns. From the point of view of efficacy, in many cases, complete resistance to the diversity of strains in both subgroups of CMV may require two transgenes, one targeting each subgroup, or otherwise a single gene that will induce PTGS to members of both subgroups. Concerning the durability of resistance, our present knowledge is insufficient, because the only CMV-resistant VRTP that has been grown at a scale greater than small field trails is the CZW-3 squash line. Although there have been no reports of resistance breakdown in CZW-3, it is grown only on a modest scale in the United States; therefore, we cannot conclude that the resistance has been challenged in the field by the full range of CMV strains to which it might be exposed, particularly on other continents. PTGS-mediated resistance has many favorable features; therefore, it would be extremely important to determine the durability of this type of resistance, because one could suspect that fairly minor sequence variations could lead to resistancebreaking strains. In order to minimize this potential problem, it is particularly important to target regions of the viral genome in which the minimum sequence variability is observed. In the comparison between PTGS- and CP-mediated resistance, one of the favorable features of the former is the absence of detectable transgene mRNA, because this eliminates messenger and viral RNA recombination as a source of potentially novel recombinants. However, it has been shown recently that the populations of recombinant CMV RNA3 molecules observed in transgenic plants expressing a CMV CP gene are not different from those in nontransgenic controls, suggesting that recombination should not be an issue for plants expressing a CMV CP gene (Turturo et al. 2008). Therefore, at this time, there are no compelling reasons to favor either type of resistance although, in the future, the issue of field durability of the different types of resistance may give a clear advantage to one resistance strategy over the other. 


\section{ACKNOWLEDGMENTS}

We thank M. Jacquemond for her helpful comments. The Plant Virology Group is supported by the Fondazione Cassamarca.

\section{LITERATURE CITED}

Aebig, J. A., Albert, H. H., Zhu, B. L., Hu, J. S., and Hsu, H. T. 2006. Cloning and construction of single-chain variable fragments $(\mathrm{scFv})$ to Cucumber mosaic virus and production of transgenic plants. Acta Hortic. 722:129-136.

Ali Rezaian, M., Ken, G., Skene, M., and Ellis, J. G. 1988. Anti-sense RNAs of Cucumber mosaic virus in transgenic plants assessed for control of the virus. Plant Mol. Biol. 11:463-471.

Anderson, J. M., Palukaitis, P., and Zaitlin, M. 1992. A defective replicase gene induces resistance to Cucumber mosaic virus in transgenic tobacco plants. Proc. Natl. Acad. Sci. U.SA. 89:8759-8763.

Asurmendi, S., Berg, R. H., Smith, T. J., Bendahmane, M., and Beachy, R. N. 2007. Aggregation of TMV CP plays a role in CP functions and in coat-protein-mediated resistance. Virology 366:98-106.

Bendahmane, M., Chen, I., Asurmendi, S., Bazzini, A. A., Szecsi, J., and Beachy, R. N. 2007. Coat protein-mediated resistance to TMV infection of Nicotiana tabacum involves multiple modes of interference by coat protein. Virology 366:107-116.

Bevan, M. W., Mason, S. E., and Goelet, P. 1985. Expression of tobacco mosaic virus coat protein by a cauliflower mosaic virus promoter in plants transformed by Agrobacterium. EMBO (Eur. Mol. Biol. Organ.) J. 4:1921-1926.

Canto, T., and Palukaitis, P. 1998. Transgenically expressed Cucumber mosaic virus RNA 1 simultaneously complements replication of $\mathrm{Cu}$ cumber mosaic virus RNAs 2 and 3 and confers resistance to systemic infection. Virology 250:325-336.

Canto, T., and Palukaitis, P. 1999. Replicase-mediated resistance to $\mathrm{Cu}$ cumber mosaic virus does not inhibit localization and/or trafficking of the viral movement protein. Mol. Plant-Microbe Interact. 12:743-747.

Canto, T., and Palukaitis, P. 2001. A Cucumber mosaic virus (CMV) RNA 1 transgene mediates suppression of the homologous viral RNA 1 constitutively and prevents CMV entry into the phloem. J. Virol. 75:9114-9120.

Canto, T., Prior, D. A., Hellwald, K. H., Oparka, K. J., and Palukaitis, P. 1997. Characterization of Cucumber mosaic virus. IV. Movement protein and coat protein are both essential for cell-to-cell movement of $\mathrm{Cu}$ cumber mosaic virus. Virology 237:237-248.

Carr, J. P., Lomonossoff, G. P., Sekiya, M. E., and Zaitlin, M. 1992. Resistance to tobacco mosaic virus induced by the $54-\mathrm{kDa}$ gene sequence requires expression of the $54-\mathrm{kDa}$ protein. Mol. Plant-Microbe Interact. 5:397-404.

Carr, J. P., Gal-On, A., Palukaitis, P., and Zaitlin, M. 1994. Replicase-mediated resistance to Cucumber mosaic virus in transgenic plants involves suppression of both virus replication in the inoculated leaves and long-distance movement. Virology 199:439-447.

Chen, Y.-K., Lohuis, D., Goldbach, R., and Prins, M. 2004. High frequency induction of RNA-mediated resistance against Cucumber mosaic virus using inverted repeat constructs. Mol. Breed. 14:215-226.

Chen, Z. L., Gu, H., Li, Y., Su, Y., Wu, P., Jiang, Z., Ming, X., Tian, J., Pan, N., and Qu, L. J. 2003. Safety assessment for genetically modified sweet pepper and tomato. Toxicology 188:297-307.

Crum, C., Johnson, J. D., Nelson, A., and Roth, D. 1988. Complementary oligodeoxynucleotide mediated inhibition of tobacco mosaic virus RNA translation in vitro. Nucl. Acids Res. 16:4569-4581.

Cuozzo, M., O'Connell, K. M., Kaniewski, W., Fang, R., Chua, N., and Tumer, N. E. 1988. Viral protection in transgenic tobacco plants expressing the Cucumber mosaic virus coat protein or its antisense RNA. Bio/Technology 6:549-555.

de Feyter, R., Young, M., Schroeder, K., Dennis, E. S., and Gerlach, W. 1996. A ribozyme gene and an antisense gene are equally effective in conferring resistance to tobacco mosaic virus on transgenic tobacco. Mol. Gen. Genet. 250:329-338.

Ding, S. W., and Voinnet, O. 2007. Antiviral immunity directed by small RNAs. Cell 130:413-426.

Doolittle, S. P. 1916. A new infectious mosaic disease of cucumber. Phytopathology 6:145-147.

Fuchs, M., Provvidenti, R., Slightom, J. L., and Gonsalves, D. 1996. Evaluation of transgenic tomato plants expressing the coat protein gene of Cucumber mosaic virus strain WL under field conditions. Plant Dis. 80:270-275

Fuchs, M., Chirco, E. M., and Gonsalves, D. 2004a. Movement of coat protein genes from a commercial virus-resistant transgenic squash into a wild relative. Environ. Biosafety Res. 3:5-16.

Fuchs, M., Chirco, E. M., McFerson, J. R., and Gonsalves, D. 2004 b.
Comparative fitness of a wild squash species and three generations of hybrids between wild $\times$ virus-resistant transgenic squash. Environ. Biosafety Res. 3:17-28.

Gal-On, A., Wolf, D., Wang, Y., Faure, J., Pilowsky, M., and Zelcer, A. 1998. Transgenic resistance to Cucumber mosaic virus in tomato: Blocking of long-distance movement of the virus in lines harboring a defective viral replicase gene. Phytopathology 88:1101-1107.

Gielen, J., Ultzen, T., Bontems, S., Loots, W., and van Schepen, A. 1996. Coat protein-mediated protection to Cucumber mosaic virus infections in cultivated tomato. Euphytica 88:139-149.

Golemboski, D. B., Lomonossoff, G. P., and Zaitlin, M. 1990. Plants transformed with a tobacco mosaic virus nonstructural gene sequence are resistant to the virus. Proc. Natl. Acad. Sci. U.S.A. 87:6311-6315.

Gonsalves, C., Xue, B., Yepes, M., Fuchs, M., Ling, K., and Namba, S. 1994. Transferring Cucumber mosaic virus-white leaf strain coat protein gene into Cucumis melo L. and evaluating transgenic plants for protection against infections. J. Am. Soc. Hortic. Sci. 119:345-355.

Gonsalves, D., Chee, P., Provvidenti, R., Seem, R., and Slightom, J. L. 1992. Comparison of coat protein-mediated and genetically-derived resistance in cucumbers to infection by Cucumber mosaic virus under field conditions with natural challenge inoculations by vectors. Bio/Technology 10:1562-1570.

Harrison, B. D., Mayo, M. A., and Baulcombe, D. C. 1987. Virus resistance in transgenic plants that express Cucumber mosaic virus satellite RNA. Nature 328:799-802.

Hellwald, K. H., and Palukaitis, P. 1994. Nucleotide sequence and infectivity of cucumber mosaic cucumovirus (strain K) RNA2 involved in breakage of replicase-mediated resistance in tobacco. J. Gen. Virol. 75:2121-2125.

Hellwald, K. H., and Palukaitis, P. 1995. Viral RNA as a potential target for two independent mechanisms of replicase-mediated resistance against Cucumber mosaic virus. Cell 83:937-946.

Honda, A., Takahashi, H., Toguri, T., Ogawa, T., Hase, S., Ikegami, M., and Ehara, Y. 2003. Activation of defense-related gene expression and systemic acquired resistance in Cucumber mosaic virus-infected tobacco plants expressing the mammalian 2'5'oligoadenylate system. Arch. Virol. 148:1017-1026.

Jacquemond, M. 1982. Phénomènes d'interférence entre les deux types d'ARN satellite du virus de la mosaïque du concombre. Protection des tomates vis à vis de la nécrose létale. C.R. Acad. Sci. Paris 294:991-994.

Jacquemond, M., and Tepfer, M. 1998. Satellite RNA-mediated resistance to plant viruses: Are the ecological risks well assessed? Pages 94-120 in: Plant Virus Disease Control. A. Hadidi, R. H. Khetarpal, and H. Koganezawa, eds.American Phytopathological Society Press, St. Paul, MN, U.S.A.

Jacquemond, M., Amselem, J., and Tepfer, M. 1988. A gene coding for a monomeric form of Cucumber mosaic virus satellite RNA confers tolerance to CMV. Mol. Plant-Microbe Interact. 1:311-316.

Jacquemond, M., Teycheney, P. Y., Carrère, I., Navas-Castillo, J., and Tepfer, M. 2001. Resistance phenotypes of transgenic tobacco plants expressing different Cucumber mosaic virus (CMV) coat protein genes. Mol. Breed. 8:85-94.

Kalantidis, K., Psaradakis, S., Tabler, M., and Tsagris, M. 2002. The occurrence of CMV-specific short RNAs in transgenic tobacco expressing virus-derived double-stranded RNA is indicative of resistance to the virus. Mol. Plant-Microbe Interact. 15:826-833.

Kaniewski, W., Ilardi, V., Tomassoli, L., Mitsky, T., Layton, J., and Barba, M. 1999. Extreme resistance to Cucumber mosaic virus (CMV) in transgenic tomato expressing one or two viral coat proteins. Mol. Breed. 5:111-119.

Kaplan, I. B., and Palukaitis, P. 1998. Characterization of Cucumber mosaic virus. VI. Generation of deletions in defective RNA 3s during passage in transgenic tobacco expressing the 3a gene. Virology 251:279-287.

Kim, S. J., Paek, K. H., and Kim, B. D. 1995. Delay in disease development in transgenic petunia plants expressing Cucumber mosaic virus $I_{17}$ N-satellite RNA. J. Am. Soc. Hortic. Sci. 120:353-359.

Kim, S. J., Lee, S. J., Kim, B.-D., and Paek, K.-H. 1997. Satellite-RNAmediated resistance to Cucumber mosaic virus in transgenic plants of hot pepper (Capsicum anпuиm cv. Golden Tower). Plant Cell Rep. 16:825-830.

Krishnan, R., McDonald, K. A., Dandekar, A. M., Jackman, A. P., and Falk, B. 2002. Expression of recombinant trichosanthin, a ribosome-inactivating protein, in transgenic tobacco. J. Biotechnol. 97:69-88.

Kwon, C. S., Chung, W. I., and Paek, K. H. 1997. Ribozyme mediated targeting of Cucumber mosaic virus RNA 1 and 2 in transgenic tobacco plants. Mol. Cells 7:326-334.

Lindbo, J. A., Silva-Rosales, L., Proebsting, W. M., and Dougherty, W. G. 1993. Induction of a highly specific antiviral state in transgenic plants: Implications for regulation of gene expression and virus resistance. Plant Cell 5:1749-1759. 
Lodge, J. K., Kaniewski, W. K., and Tumer, N. E. 1993. Broad-spectrum virus resistance in transgenic plants expressing pokeweed antiviral protein. Proc. Natl. Acad. Sci. U.S.A. 90:7089-7093.

McGarvey, P. B., Montasser, M. S., and Kaper, J. M. 1994. Transgenic tomato plants expressing satellite RNA are tolerant to some strains of $\mathrm{Cu}$ cumber mosaic virus. J. Am. Soc. Hortic. Sci. 119:642-647.

Miroshnichenko, N. A., Karpova, O. V., Morozov, S., Rodionova, N. P., and Atabekov, J. G. 1988. Translation arrest of potato virus X RNA in Krebs-2 cell-free system: RNase H cleavage promoted by complementary oligodeoxynucleotides. FEBS (Fed. Eur. Biochem. Soc.) Lett. 234:65-68.

Montasser, M. S., Tousignant, M. E., and Kaper, J. M. 1998. Viral satellite RNAs for the prevention of Cucumber mosaic virus (CMV) disease in field-grown pepper and melon plants. Plant Dis. 82:1298-1303.

Nakajima, M., Hayakawa, T., Nakamura, I., and Suzuki, M. 1993. Protection against Cucumber mosaic virus (CMV) strains $\mathrm{O}$ and $\mathrm{Y}$ and chrysanthemum mild mottle virus in transgenic tobacco plants expressing CMV-O coat protein. J. Gen. Virol. 74:319-322.

Namba, S., Ling, K., Gonsalves, C., Gonsalves, D., and Slightom, J. L. 1991. Expression of the gene encoding the coat protein of Cucumber mosaic virus (CMV) strain WL appears to provide protection to tobacco plants against infection by several different CMV strains. Gene 107:181-188.

Nejidat, A., and Beachy, R. N. 1989. Decreased levels of TMV coat protein in transgenic tobacco plants at elevated temperatures reduce resistance to TMV infection. Virology 173:531-538.

Nguyen, L., Lucas, W. J., Ding, B., and Zaitlin, M. 1996. Viral RNA trafficking is inhibited in replicase-mediated resistant transgenic tobacco plants. Proc. Natl. Acad. Sci. U.S.A. 93:12643-12647.

Niu, Q. W., Lin, S. S., Reyes, J. L., Chen, K. C., Wu, H. W., Yeh, S. D., and Chua, N. H. 2006. Expression of artificial microRNAs in transgenic Arabidopsis thaliana confers virus resistance. Nat. Biotechnol. 24:1420-1428.

Ogawa, T., Hori, T., and Ishida, I. 1996. Virus-induced cell death in plants expressing the mammalian $2^{\prime}, 5^{\prime}$ oligoadenylate system. Nat. Biotechnol. 14:1566-1569.

Okuno, T., Nakayama, M., and Furusawa, I. 1993a. Cucumber mosaic virus coat protein-mediated protection. Virology 4:357-361.

Okuno, T., Nakayama, M., Yoshida, S., Furusawa, I., and Komiya, T. 1993b. Comparative susceptibility of transgenic tobacco plants and protoplasts expressing the coat protein gene of Cucumber mosaic virus to infection with virions and RNA. Phytopathology 83:542-547.

Osbourn, J. K., Sarkar, S., and Wilson, T. M. 1990. Complementation of coat protein-defective TMV mutants in transgenic plants expressing TMV coat protein. Virology 179:921-925.

Palukaitis, P., and Garcia-Arenal, F. 2003. Cucumoviruses. Adv. Virus Res. 62:241-323

Palukaitis, P., and Roossinck, M. J. 1996. Spontaneous change of a benign satellite RNA of Cucumber mosaic virus to a pathogenic variant. Nat. Biotechnol. 14:1264-1268.

Palukaitis, P., Roossinck, M. J., Dietzgen, R. G., and Francki, R. I. 1992. Cucumber mosaic virus. Adv. Virus Res. 41:281-348.

Pang, S. Z., Bock, J. H., Gonsalves, C., Slightom, J. L., and Gonsalves, D. 1994. Resistance of transgenic Nicotiana benthamiana plants to tomato spotted wilt and impatiens necrotic spot tospoviruses: Evidence of involvement of the $\mathrm{N}$ protein and $\mathrm{N}$ gene RNA in resistance. Phytopathology 84:243-249.

Peña, L., Trad, J., Díaz-Ruiz, J. R., McGarvey, P. B., and Kaper, J. M. 1994. Cucumber mosaic virus protection in transgenic tobacco plants expressing monomeric, dimeric or partial sequences of a benign satellite RNA. Plant Sci. 100:71-81.

Pierrugues, O., Guilbaud, L., Fernandez-Delmond, I., Fabre, F., Tepfer, M., and Jacquemond, M. 2007. Biological properties and relative fitness of inter-subgroup Cucumber mosaic virus RNA 3 recombinants produced in vitro. J. Gen. Virol. 88:2852-2861.

Powell-Abel, P., Nelson, R. S., De, B., Hoffman, N., Rogers, S. G., Fraley, R. T., and Beachy, R. N. 1986. Delay of disease development in transgenic plants that express the tobacco mosaic virus coat protein gene. Science 232:738-743.

Prins, M., Laimler, M., Noris, E., Schubert, J., Wassenegger, M., and Tepfer, M. 2008. Strategies for antiviral resistance in transgenic plants. Mol. Plant Pathol. 9:73-83.

Provvidenti, R., and Gonsalves, D. 1995. Inheritance of resistance to $\mathrm{Cu}$ cumber mosaic virus in a transgenic tomato line expressing the coat protein gene of the white leaf strain. J. Hered. 86:85-88.

Qu, J., Ye, J., and Fang, R. 2007. Artificial microRNA-mediated virus resistance in plants. J. Virol. 81:6690-6699.

Quemada, H. D. 1998. The use of coat protein technology to develop virus-resistant cucurbits. Pages 147-160 in: Agricultural Biotechnology in International Development. C. L. Ives and B. M. Bedford, eds. CAB International, Wallingford, U.K.
Quemada, H. D., Gonsalves, D., and Slightom, J. L. 1991. Expression of coat protein gene from Cucumber mosaic virus strain $\mathrm{C}$ in tobacco: Protection against infections by CMV strains transmitted mechanically or by aphids. Phytopathology 81:794-802.

Register, J. C., and Beachy, R. N. 1988. Resistance to TMV in transgenic plants results from interference with an early event in infection. Virology 166:524-532.

Rizos, H., Gillings, M. R., Pares, R. D., Gunn, L. V., Frankham, R., and Daggard, G. 1996. Protection of tobacco plants transgenic for cucumber mosaic cucumovirus (CMV) coat protein is related to the virulence of the challenging CMV isolate. Aust. Plant. Pathol. 25:179-185.

Sanford, J. C., and Johnston, S. A. 1985. The concept of parasite-derived resistance-deriving resistance genes from the parasite's own genome. J. Theor. Biol. 113:395-405.

Sayama, H., Sato, T., Kominato, M., Natsuaki, T., and Kaper, J. M. 1993. Field testing of a satellite-containing attenuated strain of Cucumber mosaic virus for tomato protection in Japan. Phytopathology 83:405-410.

Shin, R., Park, J. M., An, J. M., and Paek, K. H. 2002a. Ectopic expression of Tsi1 in transgenic hot pepper plants enhances host resistance to viral, bacterial, and oomycete pathogens. Mol. Plant-Microbe Interact. 15:983-989.

Shin, R., Han, J. H., Lee, G. J., and Peak, K. H. 2002b. The potential use of a viral coat protein gene as a transgene screening marker and multiple virus resistance of pepper plants coexpressing coat proteins of Cucumber mosaic virus and Tomato mosaic virus. Transgenic Res. 11:215-219.

Simon, A. E., Roossinck, M. J., and Havelda, Z. 2004. Plant virus satellite and defective interfering RNAs: New paradigms for a new century. Annu. Rev. Phytopathol. 42:415-437.

Singh, Z., Jones, M. G. K., and Jones, R. A. C. 1998. Effectiveness of coat protein and defective replicase gene-mediated resistance against Australian isolates of Cucumber mosaic virus. Aust. J. Exp. Agric. 38:375-383.

Sleat, D. E., and Palukaitis, P. (1990) Site-directed mutagenesis of a plant viral satellite RNA changes its phenotype from ameliorative to necrogenic. Proc. Natl. Acad. Sci. USA 87:2946-2950.

Smith, N. A., Singh, S. P., Wang, M. B., Stoutjesdijk, P. A., Green, A. G., and Waterhouse, P. M. 2000. Total silencing by intron-spliced hairpin RNAs. Nature 407:319-320.

Stommel, J. R., Tousignant, M. E., Wai, T., Pasini, R., and Kaper, J. M. 1998. Viral satellite RNA expression in transgenic tomato confers field tolerance to Cucumber mosaic virus. Plant Dis. 82:391-396.

Sudarshana, M. R., Roy, G., and Falk, B. W. 2007. Methods for engineering resistance to plant viruses. Methods Mol. Biol. 354:183-195.

Suzuki, M., Masuta, C., Takanami, Y., and Kuwata, S. 1996. Resistance against Cucumber mosaic virus in plants expressing the viral replicon. FEBS (Fed. Eur. Biochem. Soc.) Lett. 379:26-30.

Taliansky, M. E., and Garcia-Arenal, F. 1995. Role of cucumovirus capsid protein in long-distance movement within the infected plant. J. Virol. 69:916-922.

Tavladoraki, P., Benvenuto, E., Trinca, S., De Martinis, D., Cattaneo, A., and Galeffi, P. 1993. Transgenic plants expressing a functional singlechain Fv antibody are specifically protected from virus attack. Nature 366:469-472

Tomassoli, L., Ilardi, V., Barba, M., and Kaniewski, W. 1999. Resistance of transgenic tomato to cucumber mosaic cucumovirus under field conditions. Mol. Breed. 5:121-130.

Tricoli, D. M., Carney, K. J., Russel, P. F., McMaster, J. R., Groff, D. W., Hadden, K. C., Himmel, P. T., Hubbard, J. P., Boeshore, M. L., and Quemada, H. D. 1995. Field evaluation of transgenic squash containing single or multiple virus coat protein gene constructs for resistance to Cucumber mosaic virus, watermelon mosaic virus 2, and zucchini yellow mosaic virus. Bio/Technology 13:1458-1465.

Tumer, N. E., Hemenway, C., O'Connell, K. M., and Cuozzo, M. 1987a Expression of coat protein genes in transgenic plants confers protection against alfalfa mosaic virus, cucumber mosaic virus and potato virus $X$. Pages 351-356 in: Plant Molecular Biology. D. von Wettstein and N.-H. Chua eds. Plenum Publishing Corporation, London, U.K.

Tumer, N. E., O'Connell, K. M., Nelson, R. S., Sanders, P. R., Beachy, R. N., Fraley, R. T., and Shah, D. M. 1987b. Expression of alfalfa mosaic virus coat protein gene confers cross-protection in transgenic tobacco and tomato plants. EMBO (Eur. Mol. Biol. Organ.) J. 6:11811188

Turturo, C., Friscina, A., Gaubert, S., Jacquemond, M., Thompson, J. R., and Tepfer, M. 2008. Evaluation of potential risks associated with recombination in transgenic plants expressing viral sequences. J. Gen. Virol. 89:327-335.

Villani, M. E., Roggero, P., Bitti, O., Benvenuto, E., and Franconi, R. 2005. Immunomodulation of Cucumber mosaic virus infection by intrabodies selected in vitro from a stable single-framework phage display library. Plant Mol. Biol. 58:305-316.

Wang, M. B., Abbot, D. C., and Waterhouse, P. M. 2000. A single copy of 
a virus-derived transgene encoding hairpin RNA gives immunity to Barley yellow dwarf virus. Mol. Plant Pathol. 1:347-356.

Watanabe, Y., Ogawa, T., Takahashi, H., Ishida, I., Takeuchi, Y., Yamamoto, M., and Okada, Y. 1995. Resistance against multiple plant viruses in plants mediated by a double stranded-RNA specific ribonuclease. FEBS (Fed. Eur. Biochem. Soc.) Lett. 372:165-168.

Wintermantel, W. M., and Zaitlin, M. 2000. Transgene translatability increases effectiveness of replicase-mediated resistance to Cucumber mosaic virus. J. Gen. Virol. 81:587-595.

Wintermantel, W. M., Banerjee, N., Oliver, J. C., Paolillo, D. J., and Zaitlin, M. 1997. Cucumber mosaic virus is restricted from entering minor veins in transgenic tobacco exhibiting replicase-mediated resistance. Virology 231:248-257.

Wisnieswski, L. A., Powell, P. A., Nelson, R. S., and Beachy, R. N. 1990. Local and systemic spread of tobacco mosaic virus in transgenic tobacco.
Plant Cell 2:559-567.

Wu, X. J., Beachy, R. N., Wilson, T. M., and Shaw, J. G. 1990. Inhibition of uncoating of tobacco mosaic virus particles in protoplasts from transgenic tobacco plants that express the viral coat protein gene. Virology 179:893-895.

Xue, B., Gonsalves, C., and Provvidenti, R. 1994. Development of transgenic tomato expressing a high level of resistance to Cucumber mosaic virus strains of subgroups I and II. Plant Dis. 78:1038-1041.

Yie, Y., Zhao, F., Zhao, S. Z., Liu, Y. Z., Liu, Y. L., and Tien, P. 1992. High resistance to Cucumber mosaic virus conferred by satellite RNA and coat protein in transgenic commercial tobacco cultivar G-140. Mol. Plant-Microbe Interact. 5:460-465.

Zaitlin, M., Anderson, J. M., Perry, K. L., Zhang, L., and Palukaitis, P. 1994. Specificity of replicase-mediated resistance to Cucumber mosaic virus. Virology 201:200-205. 